\title{
STUDY AT HOME: ANALISIS KESULITAN BELAJAR MATEMATIKA PADA PROSES PEMBELAJARAN DARING
}

\author{
Yuliza Putri Utami ${ }^{1}$, Derius Alan Dheri Cahyono ${ }^{2}$ \\ Universitas Teknokrat Indonesia ${ }^{1,2,3}$ \\ lizaputriutamilaa@gmail.com
}

\begin{tabular}{lcc}
\hline Received: Mei 2020 & Accepted: Juni 2020 & Published : Juni 2020 \\
\hline
\end{tabular}

\begin{abstract}
The e-learning study at home education system is in accordance with the 2013 curriculum. However, when the e-learning application is too difficult, it is likely that students are not able to learn mathematics optimally, as well as the amount of data that must be delivered but the internet or network access becomes slow, of course it is will disrupt student activities. This study aims to determine the learning difficulties of students towards mathematics e-learning at home. The research method used is descriptive research method. The study involved high school / MA students with data collection techniques and information through a student questionnaire response instrument using Google forms and the research subjects numbered 30 students. The student response contained 31 statement items which were the descriptions of the indicators. Indicator to measure students 'responses regarding students' learning difficulties to mathematics through the e-learning system at home. Based on the average student achievement regarding learning difficulties in mathematics e-learning that is $75 \%$ by having the lowest achievement value by students namely the implementation of interactions, assignments and teaching materials in online learning by $73 \%$ and the highest indicator achieved by students namely technical signal constraints and the inability to learn online (e-learning) that is equal to $77 \%$ and for testing the validity shows that all items are valid statements, this is because $r_{\text {count }}>$ $r_{\text {tabel }}$ and Cronbach Alpha value 0.839> reliability coefficient 0.6. After calculated using SPSS 23.
\end{abstract}

Keywords: Difficulty learning mathematics, E-learning, studying at home

\begin{abstract}
Abstrak
Sistem pendidikan e-learning study at home sesuai dengan kurikulum 2013, Namun ketika aplikasi $e$ learning terlalu sulit kemungkinan siswa tidak mampu belajar matematika secara maksimal, begitu pula ketika banyaknya data yang harus tersampaikan tetapi akses internet atau jaringan menjadi lambat, tentu saja hal tersebut akan mengganggu aktifitas siswa. Penelitian ini bertujuan untuk mengetahui kesulitan belajar siswa terhadap pelajaran matematika e-learning dirumah. Metode penelitian yang digunakan adalah metode penelitian diskriptif. Penelitian melibatkan siswa SMA/MA dengan teknik pengumpulan data dan informasinya melalui instrument angket respon siswa dengan menggunakan Google form dan subjek penelitiannya berjumlah 30 siswa. Respon siswa tersebut berisi 31 item pernyataan yang merupakan penjabaran dari indikatornya. Indikator untuk mengukur respon siswa mengenai kesulitan belajar siswa terhadap pelajaran matematika melalui sistem pendidikan e-learning dirumah. Berdasarkan rata-rata pencapaian siswa mengenai kesulitan belajar matematika e-learning yaitu $75 \%$ dengan memiliki nilai pencapaian terendah oleh siswa yaitu pelaksanaan interaksi, tugas dan bahan ajar dalam belajar online sebesar $73 \%$ dan Indikator yang paling tinggi dicapai oleh siswa yaitu kendala teknis signal dan ketidak mampuan dalam belajar online (e-learning) yaitu sebesar $77 \%$ dan untuk pengujian validitas menunjukkan bahwa seluruh item pernyataan valid, hal ini di karenakan $r_{\text {hitung }}>$ $r_{\text {tabel }}$ dan nilai Cronbach Alpha 0,839> koefisien reliabilitas 0,6. Setelah terhitung dengan menggunakan SPSS 23.
\end{abstract}

Kata Kunci: Kesulitan belajar matematika, E-learning, belajar dirumah 
Sitasi artikel ini:

Putri, Y.P. dkk. Mengenal Sejarah dan Filsafat Matematika. Jurnal Ilmiah Matematika Realistik, 1(1), 20-26.

\section{PENDAHULUAN}

Dewi \& Septa (2019) menyatakan bahwa Pendidikan pada hakikatnya adalah sebuah proses untuk menyiapkan manusia agar dapat bertahan hidup dalam lingkungannya (life skill). Pelajaran matematika merupakan mata pelajaran yang wajib dipelajari oleh siswa disetiap jenjang pendidikan baik itu SD,SMP,SMA/MA dan SMK. Ulfa (2019) menyatakan bahwa matematika dapat melatih kemampuan berpikir tingkat tinggi dalam menyelesaikan masalah. Kemampuan berpikir ini mencakup berpikir logis, kritism sistematis, dan kreatif. Namun matematika selalu dianggap sulit bagi siswa karena objek matematika yang abstrak menggunakan banyak rumus sehingga pandangan siswa terhadap pelajaran matematika di sekolah merupakan pelajaran yang sulit dan rumit untuk diterapkan dan dipahami, hal ini serupa dengan apa yang diungkapkan oleh (Ruseffendi, 2006) ia mengatakan. "Matematika dianggap sebagai ilmu yang sukar, rumit, dan memperdayakan". Puspaningtyas (2019) yang menyatakan bahwa matematika merupakan salah satu cabang ilmu pengetahuan yang dipelajari di sekolah. Pelajaran matematika tidak melulu tetang angka, tetapi jauh lebih dalam dari itu. Banyak kemampuan yang bisa dikembangkan dari pembelajaran matematika, antara lain penyelesaian masalah, komunikasi matematis, dan koneksi matematis. Oleh karena itu diharapkan pelajaran matematika menjadi salah satu mata pelajaran yang menyenangkan untuk siswa, tetapi kenyataannya masih banyak siswa yang kesulitan dalam mempelajari matematika. Peristiwa yang sering terjadi dalam pembelajaran matematika adalah siswa atau peserta didik kurang aktif, kurang berpartisipasi dalam pelajaran matematika dan peserta didik terkesan hanya sebagai pendengar sesuai yang dijelaskan atau diinformasikan oleh guru. Hal ini terjadi karena mayoritas guru masih menggunakan pembelajaran konvensioanal, terutama dengan metode ceramah. padahal seharusnya guru sebagai perencana pembelajaran yang baik dan dituntut untuk mampu merancang pembelajaran dengan memanfaatkan berbagai jenis media pembelajaran dan sumber pembelajaran yang sesuai dengan kurikulum agar proses pembelajaran tersebut berlangsung secara efektif dan efisien.

E-Learning adalah suatu sistem pembelajaran yang dapat digunakan sebagai sarana untuk proses belajar mengajar yang dilaksanakan tanpa harus bertatap muka secara langsung antara guru dengan siswa (Ardiansyah, 2013). Putri dan Dewi (2020) menyatakan bahwa seiring perkembangan zaman, seseorang dapat memperoleh informasi secara mudah melalui teknologi baru yang terus berkembang. Perkembangan teknologi ini dapat menjadi menguntungkan di bidang pendidikan bagi guru maupun siswa. Adapun manfaat dari kegiatan belajar matematika menggunakan e-learning, yaitu dengan dapat mempersingkat waktu pembelajaran atau lebih praktis dan membuat biaya pelajaran lebih ekonomis, e-learning juga dapat mempermudah interaksi siswa dengan bahan materi yang telah diberikan, siswa juga dapat saling berbagi informasi dan dapat mengakses bahan belajar setiap saat hingga berulang-ulang, dan e-learning merupakan proses pengembangan pengetahuan tidak hanya terjadi di dalam ruangan kelas saja, tetapi diluar kelas atau dirumah (study at home) dengan bantuan peralatan teknologi dan jaringan internet, sehingga para siswa dapat aktif terlibat dalam proses belajar-mengajar (Rohmah, 2016).

Walaupun demikian manfaat internet untuk pembelajaran online atau e-learning matematika memiliki banyak kekurangan di antaranya yaitu, Kurangnya interaksi antara guru dan siswa. Kurangnya interaksi ini bisa memperlambat terbentuknya penilaian serta penalaran pada pelajaran matematika dalam proses belajar dan mengajar. Kecenderunganmengabaikan aspek akademik maupun aspek sosial. Proses belajar dan mengajarnya lebih ke arah pelatihan daripada kependidikan dan mayoritas siswa tidak memiliki motivasi belajar e- learning (Yazdi, 2012).

Adapun masalah kesulitan yang sering terjadi melalui konsep diri atau Kemampuan diri ketika siswa belajar online matematika (E-learning) dirumah yaitu 1) siswa belum bisa memiliki inisiatif belajar sendiri, sehingga siswa menunggu instruksi atau pemberian tugas dari guru dalam belajar, 2) siswa belum terbiasa dalam melaksanakan kebutuhan belajar online dirumah, siswa mempelajari materi matematika sesuai apa yang diberikan oleh guru, bukan yang mereka perlukan, 3) tujuan atau target belajar online siswa terhadap pelajaran matematika masih terbatas pada perolehan nilai yang memuaskan, bukan kemampuan yang seharusnya mereka tingkatkan, 4) sebagian siswa masih belum bisa memonitor, mengatur, dan mengontrol belajar online dirumah, masih terkesan belajar yang seperlunya, 5) masih ada siswa yang menyerah mengerjakan tugas e-learning matematika ketika terdapat kesulitan dan kesalahan yang paling banyak dilakukan siswa adalah siswa jarang melakukan evaluasi proses terhadap hasil belajarnya.

Pada dasarnya global menuntut dunia pendidikan dengan menyesuaikan perkembangan teknologi terhadap kemampuannya dalam meningkatan mutu kependidikan, terutama sesuai dengan penggunaannya dalam melakukan proses pembelajaran dengan membangun infrastruktur melalui hardware, akses atau jaringan internet yang dapat dilakukan untuk memenuhi segala kebutuhan terhadap metode pembelajaran yang lebih kondusif.

Keadaan tersebut tidak boleh kita diamkan saja, perlu juga dilakukan usaha untuk meningkatkan kemandirian belajar siswa melalui sistem pendidikan e-learning dirumah (study at home), salah satu yang bisa 
diusahakan yaitu penerapan model pembelajaran matematika yang dapat memberi kesempatan terbuka bagi siswa untuk belajar secara mandiri dan siswa tidak kesulitan belajar. Maka, model pembelajaran ini harus mampu mengoptimalkan motivasi belajar siswa, serta membuat siswa terlatih belajar secara mandiri, mengefektifkan proses belajar siswa, dan siswa mampu mengimbangi pesatnya pengetahuan dan teknologi yang berkembang.

Sebenarnya alternatif model pembelajaran manapun yang akan dipilih dan digunakan tidak menjadi masalah, asalkan dengan kemampuan siswa dan tujuan akhir pembelajaran siswa teratur. Lebih jauh, penggunaan teknologi dalam pembelajaran juga sebaiknya tidak melupakan budaya. Maskar \& Anderha (2019) menyatakan bahwa berkembangnya zaman dengan ditandai kemajuan teknologi informasi berbasis internet dan robotik dengan nama revolusi industri 4.0 menjadi salah satu ancaman dan tantangan yang harus dihadapi agar keberadaan budaya tetap terjaga.

Berdasarkan latar belakang di atas, penulis melakukan penelitian untuk mengetahui analisis kesulitan belajar siswa terhadap pelajaran matematika melalui sistem pendidikan e- learning dirumah. Secara umum dalam pembelajaran e-learning dirumah (study at home) merupakan pengaplikasian yang baik sehingga dapat mengacu dalam kemampuan pengajar dan keikutsertaan siswa lebih kondusif. Namun ketika aplikasi e-learning terlalu rumit mungkin siswa tidak mampu belajar matematika secara maksimal, begitu pula ketika banyaknya data yang harus tersampaikan tetapi akses internet atau jaringan menjadi lambat, tentu saja hal tersebut akan mengganggu aktifitas siswa

\section{METODE}

Metode penelitian yang digunakan adalah metode penelitian diskriptif. Metode penelitian diskriptif tidak membuat perbandingan variabel itu pada sampel yang lain, dan mencari hubungan variabel itu dengan variabel yang lain (Sugiyono, 2016). Tujuan penelitian diskriptif yaitu untuk menjelaskan, meringkaskan berbagai kondisi (H.M Burhan Bungin, 2011). Peneliti melakukan sebuah penelitian untuk melihat (1) Bagaimanakah hasil analisis kesulitan belajar siswa terhadap pelajaran matematika melalui sistem pendidikan e-learning dirumah? (2) Bagaimana respon kesulitan belajar siswa terhadap pelajaran matematika melalui sistem pendidikan e-learning dirumah?.

Penelitian melibatkan siswa SMA/MA dengan teknik pengumpulan data dan informasinya melalui instrument angket respon siswa dengan menggunakan Google form dan subjek penelitiannya berjumlah 30 siswa. dimana aplikasi ini berguna untuk menyebarkan kuesioner secara cepat dan luas melalui link yang dibagikan kepada subjek penelitian, serta peneliti mencari referensi teori yang relefan sesuai permasalahan yang ditemukan Peneliti. Respon siswa tersebut berisi 31 item pernyataan yang merupakan penjabaran dari indikatornya. Indikator untuk mengukur respon siswa mengenai kesulitan belajar siswa terhadap pelajaran matematika melalui sistem pendidikan e-learning dirumah. Sehingga Analisis data dilakukan secara deskriptif dan Penelitian ini berusaha mendeskripsikan kesulitan belajar siswa terhadap pelajaran matematika melalui sistem pendidikan e-learning dirumah.

\section{HASIL DAN PEMBAHASAN}

Pada penelitian ini menggunakan skala pengukuran google form yang digunakan melalui skala likert yang terdiri dari Sangat setuju (SS), Setuju (S), Tidak Setuju (TS), Sangat Tidak Setuju (STS). Responden diminta untuk menjawab pernyataan yang terdapat pada kuesioner kesulitan belajar e-learning siswa dengan memilih salah satu alternatif jawaban dengan memberikan tanda centang $(\sqrt{ })$. Item - item suatu pernyataan disusun untuk mengungkap kesulitan belajar siswa terhadap pelajaran matematika melalui sistem pendidikan e-learning dirumah berupa pernyataan-pernyataan yang bersifat Favorable dan Unfavorable. Kisi-kisi suatu instrumen disajikan sebagai berikut:

Tabel 1. Kuesioner Data Google Form Sistem Pendidikan E-learning Siswal

\begin{tabular}{|c|l|c|c|c|}
\hline \multirow{2}{*}{ No } & \multicolumn{1}{|c|}{ Indikator } & \multicolumn{2}{|c|}{ No Butir } & \multirow{2}{*}{ Jumlah } \\
\cline { 3 - 4 } & $\begin{array}{c}\text { Item } \\
\text { Favourable }\end{array}$ & $\begin{array}{c}\text { Item } \\
\text { Unfavourable }\end{array}$ & \multirow{2}{*}{$\mathbf{1}$} \\
\hline & $\begin{array}{l}\text { Kendala teknis yang } \\
\text { mempengaruhi signal dan } \\
\text { ketidak mampuan dalam } \\
\text { pembelajaran online }\end{array}$ & 1,4 & $2,3,5$ & 5 \\
\hline
\end{tabular}




\begin{tabular}{|c|l|c|c|c|}
\hline $\mathbf{2}$ & $\begin{array}{l}\text { Melakukan pembelajaran, } \\
\text { membaginya melalui } \\
\text { interaksi, tugas dan bahan } \\
\text { ajar dalam pembelajaran } \\
\text { online }\end{array}$ & $6,7,9,10,13,18$, & $8,11,12,14$, & $15,16,17$ \\
\hline $\mathbf{3}$ & $\begin{array}{l}\text { Stake holder yang membantu } \\
\text { pemerintah, sekolah dan wali } \\
\text { murid dalam pembelajaran } \\
\text { online }\end{array}$ & $\begin{array}{c}20,22,23,24,25, \\
26,27,28,29,30, \\
31\end{array}$ & 21 & 12 \\
\hline \multicolumn{1}{|c|}{ Total } & 20 & 11 & 31 \\
\hline
\end{tabular}

Instrumen penilaian afektif dikembangkan melalui penelitian ini terdiri dari 31 item pernyataan tentang kesulitan belajar siswa terhadap sistem pendidikan e-learning yang tediri tiga indikator. Pengembangan instrumen ranah kesulitan belajar e-learning disesuaikan dalam ketiga indikator tersebut untuk membuat indikator penilaian terdiri dari 20 pernyataan positif dan 11 pernyataan negatif .

\section{Validitas dan reliabilitas}

Validitas adalah suatu ukuran yang akan menunjukkan tingkat kevalidan suatu instrumen. Instrumen yang valid mempunyai nilai validitas yang tinggi, sebaliknya instrumen yang kurang valid mempunyai nilai validitas yang rendah (Setyosari, 2012). Sebuah instrumen dikatakan valid apabila peneliti dapat mengukur apa yang diinginkan serta data dari variabel yang diteliti tepat karena tinggi rendahnya validitas suatu instrumen yang menunjukkan sejauh mana data tersebut terkumpul agar tidak menyimpang dari gambaran atau variabel yang dimaksud oleh peneliti. Pengujian validitas instrumen dilakukan melalui analisis korelasi product moment dengan menggunakan aplikasi SPSS 23. Berikut ini hasil validitas item dari pernyataan setelah melakukan uji coba produk:

Tabel 2. Hasil Validitas Pasca Uji coba produk

\begin{tabular}{|c|c|c|c|c|c|}
\hline \multicolumn{6}{|c|}{ Nilai Signifikasi 5\% $\left(r_{\text {tabel }}=0,361\right)$} \\
\hline $\mathrm{X} 1$ & $\mathrm{X} 2$ & $\mathrm{X} 3$ & $\mathrm{X} 4$ & $\mathrm{X} 5$ & $\mathrm{X} 6$ \\
\hline \multirow[t]{2}{*}{0,351} & 0,374 & 0,451 & 0,318 & 0,393 & 0,16 \\
\hline & & & & & 7 \\
\hline $\mathrm{X} 7$ & $\mathrm{X} 8$ & $\mathrm{X} 9$ & $\mathrm{X} 10$ & $\mathrm{X} 11$ & $\mathrm{X} 12$ \\
\hline \multirow[t]{2}{*}{0,2} & 0,322 & 0,306 & 0,361 & 0,324 & 0,54 \\
\hline & & & & & 3 \\
\hline $\mathrm{X} 13$ & $\mathrm{X} 14$ & $\mathrm{X} 15$ & $\mathrm{X} 16$ & $\mathrm{X} 17$ & $\mathrm{X} 18$ \\
\hline \multirow[t]{2}{*}{0,401} & 0,5103 & 0,44 & 0,358 & 0,366 & 0,41 \\
\hline & & & & & 7 \\
\hline $\mathrm{X} 19$ & $\mathrm{X} 20$ & $\mathrm{X} 21$ & $\mathrm{X} 22$ & $\mathrm{X} 23$ & $\mathrm{X} 24$ \\
\hline \multirow[t]{2}{*}{0,483} & 0,231 & 0,594 & 0,513 & 0,298 & 0,55 \\
\hline & & & & & 1 \\
\hline \multirow{3}{*}{$\begin{array}{c}X 25 \\
0,456\end{array}$} & $\mathrm{X} 26$ & $\mathrm{X} 27$ & $\mathrm{X} 28$ & X29 & $\mathrm{X} 30$ \\
\hline & 0,546 & 0,544 & 0,494 & 0,558 & 0,56 \\
\hline & & & & & 8 \\
\hline \multirow[t]{2}{*}{$\mathrm{X} 31$} & \multicolumn{5}{|c|}{$\begin{array}{c}r_{\text {hitung }}>r_{\text {tabel }} \\
\text { (Valid) }\end{array}$} \\
\hline & \multicolumn{5}{|c|}{$r_{\text {hitung }}<r_{\text {tabel }}$} \\
\hline 0,448 & \multicolumn{5}{|c|}{ Tidak Valid } \\
\hline
\end{tabular}


Berdasarkan 31 item pernyataan untuk skala sistem pendidikan e-learning siswa dengan pengujian validitas menunjukkan bahwa seluruh item pernyataan valid, hal ini di karenakan rhitung > rtabel. Selanjutnya akan dibahas mengenai reliabilitas berdasarkan item pernyataan.

Uji reliabilitas yaitu suatu hasil pengukuran dengan menggunakan objek yang sama, akan menghasilkan data yang sama (Sugiyono,2017). Pada aplikasi SPSS 23, metode ini dilakukan berdasarkan metode Cronbach Alpha, dimana instrumen penilaian kesulitan belajar siswa terhadap pelajaran matematika melalui sistem pendidikan e-learning dikatakan reliabel jika reliability statistics nilai Cronbach Alpha > 0,6. Berikut ini adalah hasil dari uji reliabilitas dengan menggunakan SPSS 23.

Tabel 3. Reliabilitas Hasil Uji Coba Produk.

\begin{tabular}{|c|c|}
\hline $\begin{array}{c}\text { Cronbach's } \\
\text { Alpha }\end{array}$ & $\mathrm{N}$ of Items \\
\hline ,839 & 31 \\
\hline
\end{tabular}

Berdasarkan tabel diatas dapat diketahui bahwa seluruh item pernyataan sistem pendidikan $e$-learning siswa dinyatakan reliabel. Hal ini dikarenakan nilai Cronbach Alpha $(0,839)>$ koefisien reliabilitas 0,6 . Setelah terhitung dengan menggunakan SPSS 23, hasil perhitungan indeks reliabilitas dapat dilihat pada tabel 4 berdasarkan konsultasi kriteria Guilford.

Tabel 4. Kriteria Guilford

\begin{tabular}{|c|c|c|}
\hline No & Koefisien Korelasi & Kualifikasi \\
\hline 1 & $0,91-1,00$ & Sangat Tinggi \\
\hline 2 & $0,71-0,90$ & Tinggi \\
\hline 3 & $0,41-0,70$ & Cukup Tinggi \\
\hline 4 & $0,21-0,40$ & Rendah \\
\hline 5 & Negatif $-0,20$ & Sangat Rendah \\
\hline
\end{tabular}

Hasil perhitungan diatas disesuaikan dengan kriteria Guilford. Maka reabilitas kesulitan siswa terhadap pelajaran matematika melalui sistem pendidikan e-learning termasuk katagori tinggi karena $\alpha$ memperoleh nilai sebesar 0,839 .

\section{Pencapaian Indikator Kesulitan Belajar Matematika Siswa SMA (E-Learning)}

Untuk mengetahui pencapaian indikator kesulitan belajar siswa SMA terhadap pelajaran matematika melalui sistem pendidikan e-learning study at home, maka dilakukan analisis skor kesulitan e-learning siswa untuk tiap indikator. Berdasarkan Tabel 5, diketahui bahwa rata-rata pencapaian indikator kesulitan belajar siswa terhadap pelajaran matematika melalui sistem pendidikan e-learning adalah sebesar $75 \%$. Indikator yang paling tinggi dicapai oleh siswa yaitu kendala teknis signal dan ketidak mampuan dalam belajar online (e- learning) yaitu sebesar $77 \%$.

Berdasarkan hasil tersebut tentu saja berakibat pada rendahnya kemajuan belajar yang dicapai siswa karena pembelajaran dengan konsep e-learning ini tidaklah mudah jika dibanding dengan sistem pembelajaran face-toface. Ada kemungkinan hal ini terjadi karena guru tidak mampu menerapkan konsep e-learning seperti yang telah disinggung terkait dengan keyakinan guru melalui kerangka inovasi pembelajaran menggunakan e-learning.

Perubahan konsep pembelajaran konvensional menjadi e-learning ini memang dapat dipahami karena pada kenyataannya memang tidaklah mudah untuk mengubah kebiasaan dan keyakinan dalam belajar mengajar yang sudah menjadi kebiasaan dalam jangka waktu yang panjang, padahal Kehebatan e-Learning, ini dapat menghemat dan bahkan dapat menghilangkan dua masalah besar, yang selalu muncul dalam upaya meningkatkan konsep belajar sinambung dari suatu institusi, yaitu waktu dan biaya. Meskipun demikan, pada kenyataannya e-learning seringkali dilaksanakan karena ketidaksempurnaan metode yang digunakan dan buruknya bahan ajar yang dipakai. 
Tabel 5. Pencapaian Indikator Kesulitan Belajar Online (E-Learning) Siswa

\begin{tabular}{|c|l|c|c|c|}
\hline No & \multicolumn{1}{|c|}{ Indikator } & Skor yang Dicapai & Skor Total & Pencapaian (\%) \\
\hline 1. & $\begin{array}{l}\text { Kendala teknis signal dan } \\
\text { ketidak mampuan dalam belajar } \\
\text { online }\end{array}$ & 2307 & 3000 & 77 \\
\hline 2. & $\begin{array}{l}\text { Pelaksanaan interaksi, tugas dan } \\
\text { bahan ajar dalam belajar online }\end{array}$ & 6118 & 8400 & 73 \\
\hline 3. & $\begin{array}{l}\text { Stake holder membantu } \\
\text { pemerintah, sekolah, wali murid } \\
\text { dalam belajar online }\end{array}$ & 5429 & 7200 & 75 \\
\hline & Rata-Rata Pencapaian & \\
\hline
\end{tabular}

Penelitian dan pengembangan yang telah dilaksanakan dari instrumen penilaian afektif berbasis google form untuk mengukur kesulitan belajar siswa terhadap pelajaran matematika melalui sistem pendidikan e-learning. Sehingga memudahkan peneliti untuk menilai kesulitan siswa dan ekonomis sebab tidak memerlukan kertas ataupun alat tulis lainnya dengan jumlah yang banyak, serta data dapat dilakukan secara langsung pada aplikasi SPSS. Letak kesulitan belajar siswa berkaitan erat dengan kesalahan siswa dalam menyelesaikan masalah matematika, hal itu dapat dilihat ketika siswa tidak mampu mencapai suatu indikator tertentu dari pernyataan tersebut.

Berdasarkan rata-rata pencapaian siswa mengenai kesulitan belajar matematika e-learning yaitu $75 \%$ dengan memiliki nilai pencapaian terendah oleh siswa yaitu pelaksanaan interaksi, tugas dan bahan ajar dalam belajar online sebesar $73 \%$ dan Indikator yang paling tinggi dicapai oleh siswa yaitu kendala teknis signal dan ketidak mampuan dalam belajar online (e-learning) yaitu sebesar 77\%. Hal ini menunjukkan bahwa kesulitan belajar siswa terhadap pelajaran matematika melalui sistem pendidikan e-learning bernilai tinggi oleh karena itu dapat disimpulkan siswa kurang menguasai pembelajaran e-learning terhadap pelajaran matematika. Dapat dilihat dari data google form tersebut ada beberapa kendala yang dihadapi siswa, sesuai indikator kendala teknis signal dan ketidak mampuan dalam belajar online (e-learning) antara lain sebagai berikut:

\begin{tabular}{|c|c|c|c|}
\hline $\begin{array}{c}\text { Siswa sering } \\
\text { mengalami kendala } \\
\text { terkait signal internet } \\
\text { yang ia pakai. }\end{array}$ & $\begin{array}{c}\text { Jumlah tugas yang } \\
\text { banyak membuat siswa } \\
\text { kesulitan dalam } \\
\text { mengerjakan pelajaran } \\
\text { matematika }\end{array}$ & $\begin{array}{c}\text { Siswa kurang minat } \\
\text { belajar daring karena } \\
\text { ia menjadi kurang } \\
\text { mampu belajar } \\
\text { mandiri }\end{array}$ & $\begin{array}{l}\text { Saya tidak memahami } \\
\text { tentang pembelajaran } \\
\text { dalam jaringan }\end{array}$ \\
\hline
\end{tabular}

Gambar 1. Kesulitan Belajar E-learning Siswa

Indikator yang paling tinggi dicapai oleh siswa yaitu kendala teknis signal dan ketidak mampuan dalam belajar online ini karena siswa tidak menerima konsep langsung antara guru dan siswa maka ketika menemukan soal yang sulit siswa cendrung menegosiasikannya dengan menerima keadaan atau pasrah dan diam karena ketidak pahamannya siswa terhadap pelajaran matematika melalui e-learning.

Berdasarkan hasil tersebut tentu saja berakibat pada rendahnya kemajuan belajar yang dicapai siswa karena pembelajaran dengan konsep e-learning ini tidaklah mudah jika dibanding dengan sistem pembelajaran face-to-face. Ada kemungkinan hal ini terjadi karena guru tidak mampu menerapkan konsep e-learning seperti yang telah disinggung terkait dengan keyakinan guru melalui kerangka inovasi pembelajaran menggunakan elearning.

Perubahan konsep pembelajaran konvensional menjadi e-learning ini memang dapat dipahami karena pada kenyataannya memang tidaklah mudah untuk mengubah kebiasaan dan keyakinan dalam belajar mengajar yang sudah menjadi kebiasaan dalam jangka waktu yang panjang, padahal Kehebatan e-Learning, ini dapat menghemat dan bahkan dapat menghilangkan dua masalah besar, yang selalu muncul dalam upaya meningkatkan konsep belajar sinambung dari suatu institusi, yaitu waktu dan biaya. Meskipun demikan, pada kenyataannya e-learning seringkali dilaksanakan karena ketidaksempurnaan metode yang digunakan dan buruknya bahan ajar yang dipakai.

Berbagai kendala yang muncul dari sistem pembelajaran tatap muka menuju sistem pembelajaran elearning kiranya dapat membantu pendidik yang berkompeten dalam menyusun suatu perencanaan sehingga proses terhadap pengaruh pembelajaran terkait dengan perubahan ini dapat dilakukan secara lebih baik dan lebih terencana. 
Adapun solusi untuk mengatasi kesulitan belajar matematika e-learning sesuai hasil kesulitan siswa yang dihadapinya untuk itu penerapan pembelajaran e-learning matematika yang menarik dan menyenangkan bagi pelajar masih sangat diperlukan berbagai cara dalam mengembangkan inovasi pembelajaran dan pemenuhan sarana prasarana pendidikan. Pembelajaran berbasis web atau sering disebut e-learning (electronic learning) dapat didefinisikan sebagai aplikasi teknologi web dalam dunia pembelajaran matematika ataupun pelajaran lainnya.

Secara sederhana bahwa dapat dikatakan seluruh mata pelajaran dapat dilakukan dengan cara yang mudah melalui pemanfaatan teknologi internet, maka kegiatan tersebut disebut e-learning. Kemudian, teknologi juga mempunyai kecepatan serta tidak terbatasnya tempat dan waktu untuk mengakses informasi, komunikasi . Kegiatan belajar e-learning dapat dilakukan dengan oleh peserta didik kapan saja dan dimana saja. Batas ruang, jarak dan waktu tidak lagi menjadi masalah yang rumit untuk dipecahkan.

\section{SIMPULAN}

Berdasarkan hasil penelitian ini diperoleh kesimpulan bahwa E-learning dapat membantu dalam menguasai materi sehingga materi yang diharapkan dapat meningkatkan kesadaran bahwa belajar itu penting dan menyenangkan, terutama pelajaran matematika berguna mencapai prestasi yang maksimal, sehingga memberikan pengaruh yang positif terhadap pelajaran matematika, terjadi peningkatan hasil belajar matematika, sikap dan kinerja siswa juga baik dalam mengikuti pembelajaran sehingga terjadi peningkatan pemahaman siswa pada materi yang sudah dipelajari. Namun ketika aplikasi e-learning terlalu rumit mungkin siswa tidak mampu belajar matematika secara maksimal, begitu pula ketika banyaknya data yang harus tersampaikan tetapi akses internet atau jaringan menjadi lambat, tentu saja hal tersebut akan mengganggu aktifitas siswa. Sebenarnya alternatif model pembelajaran manapun yang akan dipilih dan digunakan tidak menjadi masalah, asalkan dengan kemampuan siswa dan tujuan akhir pembelajaran siswa teratur.

Adapun saran dari peneliti yaitu pengelolaan waktu perlu dipertimbangkan lagi dalam setiap pelaksanaan model pembelajaran, sehingga semua aktivitas siswa diharapkan dapat dikembangkan sesuai dengan tujuan pembelajaran dan pendidik harus memahami pembelajaran e-learning agar pembelajaran dapat terlaksana secara efektif, sehingga harapan dan kualitas pembelajaran siswa meningkat namun diperlukan juga untuk melakukan analisis terhadap pembelajaran yang akan dilakukan agar penerapan e-learning dapat berjalan lancar.

\section{REFERENSI}

Dewi, P.S., \& Septa, H.W. (2019). Peningkatan Kemampuan Pemecahan Masalah dan Disposisi Matematis Siswa dengan Pembelajaran Berbasis Masalah. Mathema: Journal Pendidikan Matematika. 1(1), 31-39.

H.M Burhan Bungin. (2011). Metode Penelitian Kuntitatif: Komunikasi, Ekonomi, dan Kebijakan Publik serta Ilmu-ilmu lainnya, Edisi Kedua (2nd ed.). Jakarta: Kencana Prenama Media Group.

Maskar, S. \& Anderha, R. R. (2019). Pembelajaran Transformasi Geometri dengan Pendekatan Motif Kain Tapis Lampung.Mathema: Jurnal Pendidikan Metematika. 1(1), 40-47

Puspaningtyas, N. D. (2019). Berpikir Lateral Siswa SD dalam Pembelajaran Matematika. Mathema: Jurnal Pendidikan Matematika. 1(1), 25-30

Putri, L.A., \& Dewi, P.S. (2020). Media Pembelajaran Menggunakan Video Atraktif pada Materi Garis Singgung Lingkaran. Mathema Journal Pendidikan Matematika. 2(1), 32-39.

Ramadhani, Mawar. (2012). Efektivitas Penggunaan Media Pembelajaran Elearning Berbasis Web Pada Pembelajaran Teknologi Informasi dan Komunikasi Terhadap Hasil Belajar Siswa Kelas X SMA Negeri 1 Kalasan.Yogyakarta: Tidak Diterbitkan

Rohmah, L., (2016). Konsep E-Learning Dan Aplikasinya Pada Lembaga Pendidikan Islam. An-Nur: Jurnal Studi Islam. 3(2),

Ruseffendi, E.T, 2006, Pengantar Kepada Guru Mengembangkan Kompetensinya dalam Pengajaran Matematika Untuk Meningkatkan CBSAl. Bandung: Tarsito.

Setyosari, punaji. 2012. Metode Penelitian Pengembangan. Jakarta: Kencana. Sugiyono. 2016. Metode Penelitian Kombinasi (8th ed.). Bandung: Alfabeta.

Ulfa, M. (2019). Strategi Preview, Question, Read, Reflect, Recite, Review (PQ4R) pada Pemahaman Konsep Matematika. Mathema Journal Pendidikan Matematika. 1(1), 48-55.

Yazdi, M. 2012. E-Learning Sebagai Media Pembelajaran Interaktif Berbasis Teknologi Informasi. Jurnal Ilmiah Foristek. 2(1). 